\title{
INFLORESCENCE PRODUCTION OF BROCCOLI CULTIVARS IN THE HOT AND HUMID CLIMATE OF CENTRAL AMAZONIA ${ }^{1}$
}

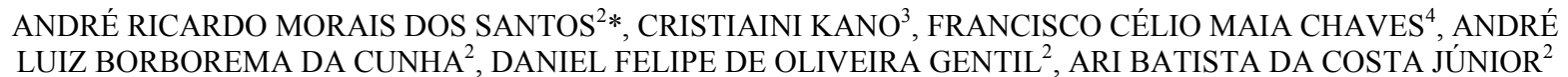

\begin{abstract}
Broccoli has great economic, social, and nutritional importance. Genetic improvements through breeding programs for this species made available cultivars with satisfactory production in hot and humid climates. Two experiments were conducted to evaluate the inflorescence production of broccoli cultivars (Ramoso and Cabeça groups) in the hot and humid climate of Central Amazonia. In experiment 1, Ramoso group cultivars were evaluated (Verão Ramoso Piracicaba, Ramoso Santana, Piracicaba, Piracicaba Precoce, Ramirez F1, Hanabi, Piracicaba Precoce Verão, and Hanapon). In experiment 2, Cabeça group cultivars were evaluated (Green Storm, Strong, TPX-00925, Salinas F1, Bibou, Domador, Burney, and BRO 68). A randomized block experimental design was used, with eight treatments consisted of cultivars, and four replications for each experiment. Quantitative variables were evaluated, including inflorescence fresh and dry weights; and the qualitative variables evaluated showed the occurrence of undesirable characteristics in the inflorescences. Significant differences were found within the Ramoso group cultivars and within the Cabeça group cultivars evaluated. The broccoli cultivars that showed the best inflorescence production in the humid, hot climate of Central Amazonia were Verão Ramoso Piracicaba, Piracicaba Precoce Verão, Ramoso Santana, and Piracicaba Precoce of the Ramoso group; and Green Storm and Burney of the Cabeça group.
\end{abstract}

Keywords: Brassica oleracea var. italica. Cultivar evaluation. Production quality. Inflorescence characteristics.

\section{PRODUÇÃO DE INFLORESCÊNCIAS DE CULTIVARES DE BRÓCOLIS EM CLIMA QUENTE E ÚMIDO DA AMAZÔNIA CENTRAL}

\begin{abstract}
RESUMO - O brócolis possui grande importância econômica, social e nutricional. O melhoramento genético desta cultura disponibilizou cultivares com produção satisfatória em clima quente e úmido. Para avaliar cultivares de brócolis dos grupos "ramoso" e "cabeça" de maior produção de inflorescências em clima quente e úmido da Amazônia Central foram desenvolvidos dois experimentos. No experimento 1 foram avaliadas as cultivares do grupo "ramoso"(Verão Ramoso Piracicaba, Ramoso Santana, Piracicaba, Piracicaba Precoce, Ramirez F1, Hanabi, Piracicaba Precoce Verão e Hanapon). No experimento 2, cultivares do grupo "cabeça" (Green Storm, Strong, TPX-00925, Salinas F1, Bibou, Domador, Burney e BRO 68). O delineamento experimental foi o de blocos casualizados com oito tratamentos, representados pelas cultivares, e quatro repetições para cada experimento. Foram analisadas variáveis quantitativas, dentre as quais, massa fresca e seca das inflorescências e variáveis qualitativas que evidenciaram a ocorrência de características indesejáveis nas inflorescências. Houve diferença estatística significativa entre as cultivares do grupo "ramoso" entre si e do grupo "cabeça" entre si. As cultivares de brócolis que apresentaram melhor produção de inflorescências em clima quente e úmido da Amazônia Central foram Verão Ramoso Piracicaba, Piracicaba Precoce Verão, Ramoso Santana e Piracicaba Precoce do grupo "ramoso", e Green Storm e Burney do grupo "cabeça".
\end{abstract}

Palavras-chave: Brassica oleracea var. italica. Avaliação de cultivares. Qualidade da produção. Características das inflorescências.

\footnotetext{
${ }^{*}$ Corresponding author

${ }^{1}$ Received for publication in $15 / 02 / 2019$; accepted in $10 / 22 / 2019$.

Paper extracted from the masters dissertation of the first author.

${ }^{2}$ Faculty of Agricultural Sciences, Universidade Federal do Amazonas, Manaus, AM, Brazil; andrermsantos.agro@gmail.com - ORCID: 0000-0003-4063-1619, andre_am10@hotmail.com - ORCID: 0000-0002-5502-2093, dfgentil@ufam.edu.br - ORCID: 0000-0002-44621330, a.junior21@hotmail.com - ORCID: 0000-0002-4881-1166.

${ }^{3}$ Embrapa Territorial, Campinas, SP, Brazil; cristiaini.kano@embrapa.br-ORCID: 0000-0001-8113-7065.

${ }^{4}$ Embrapa Amazônia Ocidental, Manaus, AM, Brazil; celio.chaves@embrapa.br - ORCID: 0000-0002-4164-8511.
} 


\section{INTRODUCTION}

The species Brassica oleracea var. italica, known as broccoli, is an herbaceous vegetable from the Brassicaceae family. It comprises two groups: Ramoso, which has several lateral inflorescences; and Cabeça, which has a unique inflorescence. Seed companies have developed open-pollinated and hybrid cultivars with wide adaptation to different climate conditions. These hybrids can be classified as summer or winter hybrid, according to their adaptation to the climate conditions of these seasons (BHERING, 2013).

Broccoli consumption has shown significant increase because of its nutritional, nutraceutical, and anticancer properties due to the presence of bioactive compounds with antioxidant capacity. Broccoli production is intended to fresh consumption, minimum processing, and freezing products, which are quick and easy to prepare (TREVISAN, 2013).

Broccoli production is very promising because it is economically, socially, and nutritionally important, and allows for diversification of production, generation of income, direct and indirect employment, and a beneficial diet for consumers (EMBRAPA, 2015). However, the profitability of this activity in regions with specific climate characteristics requires that producers know the production costs and achieve satisfactory production and adequate economic return (MELO et al., 2009).

Reis and Madeira (2009) pointed out that the main problems for vegetables crops in the state of Amazonas, Brazil, is the low number of technicians specialized in olericulture; the hot, humid local climate of this region, which is unfavorable to conventional vegetable crops; the occurrence of phytosanitary problems; the lack of cultivars that are adapted to the region; and other technical problems.

The evaluation of broccoli cultivars in different climates is essential to understand the dynamics of these plants and their tolerance to different natural adverse climate conditions, such as high temperature and rainfall depths. Thus, studies on the performance of cultivars in regions with different edaphoclimatic characteristics are important to identify cultivars with phenotypic characteristics adapted to local soil and climate conditions, and to subsidize subsequent researches for the use of cultivars with better agronomic characteristics; they are also useful to define planting seasons and the most appropriate crop systems, increase crop profitability and the offering of this product for the market, and enable the consumers to have a richer, more diverse, and healthier diet (TREVISAN et al., 2003).

Researches on broccoli breeding have developed cultivars adapted to hot and humid climates. These cultivars are tolerant to the detrimental effects of abiotic stress conditions and can maintain high yield because of their good photosynthetic response (GURURANI et al., 2015).

Broccoli production in Amazonia is little studied; but the study conducted by Blind et al. (2015) can be highlighted for this crop in Amazonia. Thus, considering the high market value of this vegetable in the region, the conduction of experiments for this plant species is necessary to develop different production systems, growing seasons, cultural practices, and promising cultivars for production. In this context, the objective of the present work was to evaluate broccoli cultivars of the Ramoso and Cabeça groups in the hot and humid conditions of Central Amazonia, characterizing their inflorescence production for recommendation of cultivars.

\section{MATERIAL AND METHODS}

This work consisted of two experiments. In experiment 1, broccoli cultivars of the Ramoso group were evaluated: Verão Ramoso Piracicaba (Horticeres ${ }^{\circledR}$ ), Ramoso Santana $\quad$ Topseed $^{\circledR}$ ), Piracicaba (Topseed $\left.{ }^{\circledR}\right)$, Piracicaba Precoce $\left(\right.$ Feltrin $\left.^{\circledR}\right)$, Ramirez F1 (Topseed ${ }^{\mathbb{B}}$ ), Hanabi $\left(\right.$ Sakata $\left.^{\circledR}\right)$, Piracicaba Precoce Verão $\left(\right.$ Sakata $\left.^{\circledR}\right)$, and Hanapon $\left(\right.$ Sakata $\left.^{\circledR}\right)$. In experiment 2, Cabeça group cultivars were evaluated: Green Storm (Isla ${ }^{\circledR}$ ), Strong (Isla ${ }^{\circledR}$ ), TPX-00925 (Topseed $^{\circledR}$ ), Salinas F1 (Topseed ${ }^{\circledR}$ ), Bibou $\left(\right.$ Feltrin $\left.^{\circledR}\right)$, Domador (Horticeres ${ }^{\circledR}$ ), Burney $\left(\right.$ Bejo $\left.^{\circledR}\right)$, and BRO $68\left(\right.$ Syngenta $\left.^{\circledR}\right)$.

The experiments were conducted simultaneously in an open field from August 2016 to January 2017, in Manaus, Amazônas (AM), Brazil, at the Medicinal and Vegetable Plant Sector of the Brazilian Agricultural Research Corporation (Embrapa Western Amazon), located by the AM010 Highway $\left(02^{\circ} 53^{\prime} 25^{\prime \prime} \mathrm{S}, 59^{\circ} 58^{\prime} 06^{\prime \prime} \mathrm{W}\right.$, and altitude of $102 \mathrm{~m})$. The local climate is Af, equatorial hot and humid, according to the Köppen classification, with annual average temperature of $26.7{ }^{\circ} \mathrm{C}$ and annual average rainfall depth of $2,420 \mathrm{~mm}$ (ALVARES, et al., 2013). The soil of the area was classified as dystrophic Typic Hapludox (Latossolo Amarelo; EMBRAPA, 2013) of clayey texture, which is characteristic of the upland Amazonian ecosystem. The soil presented the following chemical characteristics: $\mathrm{pH}\left(\mathrm{H}_{2} \mathrm{O}\right)$ of $5.3,31.95 \mathrm{~g} \mathrm{~kg}^{-1}$ of organic matter, $11 \mathrm{mg} \mathrm{dm}^{-3}$ of $\mathrm{P}, 53 \mathrm{mg} \mathrm{dm}^{-3}$ of $\mathrm{K}, 1$ $\mathrm{mg} \mathrm{dm}{ }^{-3}$ of $\mathrm{Na}, 1.87 \mathrm{cmol}_{\mathrm{c}} \mathrm{dm}^{-3}$ of $\mathrm{Ca}, 0.96 \mathrm{cmol}_{\mathrm{c}}$ $\mathrm{dm}^{-3}$ of $\mathrm{Mg}, 0.06 \mathrm{cmol}_{\mathrm{c}} \mathrm{dm}^{-3}$ of $\mathrm{Al}, 1.55 \mathrm{cmol}_{\mathrm{c}} \mathrm{dm}^{-3}$ of $\mathrm{H}+\mathrm{Al}$, and base saturation of $65.84 \%$.

A randomized block experimental design was used, with eight treatments (cultivars) and four replications. The plots consisted of two $3.5 \mathrm{~m}$ long rows containing 14 plants, with spacing of $1.0 \mathrm{~m}$ between rows and $0.5 \mathrm{~m}$ between plants, totaling 7.0 $\mathrm{m}^{2}$. The evaluation area of the plot consisted of the ten central plants, disregarding one plant from each end of the rows, comprising an area of $5.0 \mathrm{~m}^{2}$. The 
borders of the experimental area consisted of two rows with the evaluated broccoli cultivars planted.

Soil acidity was corrected, and planting and topdressing fertilization were applied as recommended by Trani et al. (1997) for broccoli crops. The seedlings were produced in August 2016, using 72-cell expanded polystyrene trays with a commercial substrate based on pine bark. The seedlings were transplanted in September 2016. The plants were irrigated using a drip irrigation system. The occurrence of pests and diseases was monitored, and they severity and incidence were always below the control level. Weeds were controlled through manual weeding every 15 days.

The harvests of all cultivars started at 60 days after the transplant and lasted 45 days, during the period when the inflorescences showed greater development and their flower buds were still closed. Three harvests were carried out per plant for the Ramoso group cultivars, with 7-day intervals, as the plants emitted new inflorescences; the harvests were done by cutting their stem at one centimeter from the stalk. One harvest was done per plant for the Cabeça group cultivars, leaving inflorescence stalks of one centimeter and observing the senescence of the plant after harvest.

In experiment 1 , the characteristics evaluated were: number of inflorescences (unit plant ${ }^{-1}$ ), by counting and summing the number of stems in each harvest; inflorescence fresh weight $\left(\mathrm{g} \mathrm{plant}^{-1}\right)$, by separating and determining the weights of flower buds, stems, leaves, and total inflorescences, using a balance; inflorescences dry weight $\left(\mathrm{g} \mathrm{plant}^{-1}\right)$, by drying the flower buds, stems, and leaves in a forced -air circulation oven at $65{ }^{\circ} \mathrm{C}$ until constant weight and, subsequently, weighing the flower buds, stems, leaves, and total inflorescences.

In experiment 2 the characteristics evaluated were: presence of leaves in the inflorescence, using a scale of grades ranging from 1 to 5 , considering the number of leaves $(1=>30 ; 2=21$ to $30 ; 3=11$ to $20 ; 4=1$ to $10 ; 5=0)$; absence or presence of anthocyanin (purple pigmentation) in the inflorescence, using 1 for absence, and 2 for presence; flower bud size, using a scale of grades ranging from 1 to $5(1=$ very thick, $2=$ thick, $3=$ medium, $4=$ thin, and $5=$ very thin); premature opening of flower buds, using a scale of grades ranging from 1 to $5(1=$ very severe, $2=$ severe, $3=$ medium, $4=$ small, and $5=$ nonexistent); arrangement of florets, using a scale of grades ranging from 1 to $4(1=$ flat with loose florets, $2=$ slightly rounded with loose florets, 3 = round with loose florets, and $4=$ round with cohesive florets; absence or presence of hollow stems in inflorescence, using 1 for absence, and 2 for presence; floral peduncle diameter $(\mathrm{cm})$, largest inflorescence diameter $(\mathrm{cm})$, and perpendicular to largest inflorescence diameter $(\mathrm{cm})$, which were measured with a caliper ruler; relative inflorescence diameter, using the ratio between the largest and perpendicular diameters of the inflorescence; inflorescence fresh weight $\left(\mathrm{g}\right.$ plant $\left.{ }^{-1}\right)$, by weighing the fresh inflorescences on a balance; inflorescence dry weight $\left(\mathrm{g}\right.$ plant $\left.{ }^{-1}\right)$, obtained after drying the inflorescence at $65{ }^{\circ} \mathrm{C}$ in a forced air-circulation oven until constant weight and, subsequently, weighing on a balance.

The data of each experiment were subjected to analysis of variance by the F test and, when the effect of the treatments was significant, the Scott Knott test was applied at 5\% probability to compare the means of the treatments.

\section{RESULTS AND DISCUSSION}

The inflorescence production of broccoli cultivars of the Ramoso and Cabeça groups in the hot and humid conditions of Central Amazonia varied between the different cultivars evaluated, in qualitative and quantitative terms, showing the effect of the genotype of each cultivar (TAN et al., 1999).

In experiment 1, significant differences between the Ramoso group cultivars evaluated were found for number of inflorescences per plant, fresh flower bud weight (Table 1), and dry flower bud weight (Table 2).

The cultivars that presented the highest number of inflorescences per plant were Verão Ramoso Piracicaba and Piracicaba Precoce Verão (Table 1). Similar results were found by Blind et al. (2015), who evaluated the production of broccoli inflorescences of the Ramoso group in Presidente Figueiredo, AM, Brazil, and found number of inflorescences per plant of 28 and 57 for the cultivars Ramoso Piracicaba and Ramoso Santana, respectively; they observed the effect of the cultivar on broccoli yield, denoting the importance of choosing cultivars for commercial crops.

The highest fresh flower bud weights were found for the cultivars Piracicaba Precoce Verão, Verão Ramoso Piracicaba, Ramoso Santana, and Piracicaba Precoce (Table 1). This characteristic represents the most valued inflorescence portion for consumption and depends on the acclimatization of each cultivar, which increases photosynthetic capacity and respiratory flow and allocates great amounts of photoassimilates to flower buds (LEAKEY et al., 2009).

The fresh stem weight, fresh leaf weight, and total fresh inflorescence weight presented no significant differences between cultivars (Table 1). The cultivars formed similar stems and leaves of inflorescences under the hot and humid climate to which they were subjected. Bjorkmam and Pearson (1998) found that the effect of excessive heat on 
broccoli crops is specifically harmful at the differentiation phase of flower buds, and less harmful at the vegetative phase and when flower buds are already formed.

Table 1. Means for number of inflorescences per plant (NI), fresh flower bud weight (FFBW), fresh stem weight (FSW), fresh leaf weight (FLW), and total fresh inflorescence weight (TFIW), in grams per plant, of broccoli cultivars of the Ramoso group grown in the hot and humid conditions of Central Amazonia. Manaus, AM, Brazil, 2016/2017.

\begin{tabular}{lccccc}
\hline \multicolumn{1}{c}{ Cultivar } & $\begin{array}{c}\text { NI } \\
\text { unit plant }\end{array}$ & FFBW & FSW & FLW & TFIW \\
\hline Verão Ramoso Piracicaba & $53 \mathrm{a}$ & $123.91 \mathrm{a}$ & 173.11 & 113.23 & 400.40 \\
Ramoso Santana & $40 \mathrm{~b}$ & $108.21 \mathrm{a}$ & 179.23 & 122.54 & 383.81 \\
Piracicaba & $35 \mathrm{~b}$ & $59.79 \mathrm{~b}$ & 146.48 & 114.57 & 302.65 \\
Piracicaba Precoce & $38 \mathrm{~b}$ & $92.79 \mathrm{a}$ & 153.52 & 106.70 & 345.48 \\
Ramirez & $33 \mathrm{~b}$ & $80.80 \mathrm{~b}$ & 147.10 & 101.93 & 316.10 \\
Hanabi & $37 \mathrm{~b}$ & $71.06 \mathrm{~b}$ & 162.61 & 77.33 & 317.82 \\
Piracicaba Precoce Verão & $49 \mathrm{a}$ & $123.95 \mathrm{a}$ & 174.36 & 114.28 & 363.96 \\
Hanapon & $17 \mathrm{c}$ & $42.36 \mathrm{~b}$ & 121.76 & 107.73 & 246.79 \\
\hline Coefficient of variation (\%) & 24.8 & 23.3 & 29.7 & 26.7 & 30.7 \\
\hline
\end{tabular}

Means followed by the same letter in the columns are not different by the Scott Knott test at $5 \%$ probability.

The total fresh inflorescence weight per plant found was similar to the means presented by Blind et al. (2015), who reported 386 to $433 \mathrm{~g} \mathrm{plant}^{-1}$ in a study conducted under similar climate conditions; but lower than those found by Melo and Giordano (1999), when developing the cultivar Ramoso de Brasilia, which reached a total fresh inflorescence weight of $720 \mathrm{~g} \mathrm{plant}^{-1}$ in Brasilia, DF, during winter and a mild summer.
The cultivars Piracicaba Precoce Verão and Verão Ramoso Piracicaba had higher dry flower bud weights (Table 2). This characteristic is determined by environmental conditions, intrinsic controls of each cultivar, and plant development (WAHID et al., 2007). Therefore, these cultivars were more efficient in distributing biomass to the inflorescence parts that have greater commercial interest (flower buds), indicating greater adaptation to the local climate.

Table 2. Means for dry flower bud weight (DFBW), dry stem weight (DSW), dry leaf weight (DLW), and total dry inflorescence weight (TDIW), in grams per plant, of broccoli cultivars of the Ramoso group grown in the hot and humid conditions of Central Amazonia. Manaus, AM, Brazil, 2016/2017.

\begin{tabular}{lcccc}
\hline \multicolumn{1}{c}{ Cultivar } & DFBW & DSW & DLW & TDIW \\
\hline Verão Ramoso Piracicaba & $12.42 \mathrm{a}$ & 13.28 & 12.99 & 38.68 \\
Ramoso Santana & $9.72 \mathrm{~b}$ & 14.93 & 13.73 & 38.26 \\
Piracicaba & $9.77 \mathrm{~b}$ & 12.16 & 12.70 & 30.86 \\
Piracicaba Precoce & $9.54 \mathrm{~b}$ & 11.76 & 11.11 & 32.41 \\
Ramirez & $7.73 \mathrm{c}$ & 14.81 & 7.50 & 27.38 \\
Hanabi & $10.09 \mathrm{~b}$ & 11.38 & 13.02 & 40.02 \\
Piracicaba Precoce Verão & $13.49 \mathrm{a}$ & 15.95 & 11.26 & 18.59 \\
Hanapon & $4.27 \mathrm{~d}$ & 6.74 & 28.6 & 32.8 \\
\hline Coefficient of variation (\%) & 16.5 & 29.6 & \\
\hline
\end{tabular}

Means followed by the same letter in the columns are not different by the Scott Knott test at $5 \%$ probability.

The dry stem weight, dry leaf weight, and total dry inflorescence weight presented no significant differences between cultivars (Table 2), denoting that the formation of vegetative structures (stems and leaves) of inflorescences is less affected by temperature than the flower bud formation (BOOIJ; STRUIK, 1990).

In experiment 2, under the conditions in which the Cabeça group cultivars evaluated were grown, the cultivar Strong presented vegetative development equivalent to that of the other cultivars, but with no inflorescence formation; this was probably because of the low tolerance of this cultivar to hot climates, which prevented the differentiation of meristems into flower buds (LALLA et al., 2010).

The cultivar Domador should form inflorescences that are characteristic of the Cabeça group, according to information from the company responsible for its marketing; however, it presented the same vegetative development as the other cultivars, and emitted inflorescences sometimes characteristic of the Cabeça group and sometimes characteristic of the Ramoso group, denoting an effect of their response to the high temperatures.

Thus, the cultivars Strong and Domador were excluded from the statistical analysis because they did not have the adequate characteristics of the Cabeça group. 
Regarding the presence of leaves in the inflorescence, which is an undesirable characteristic in broccoli production, the cultivars that presented lower occurrence were the Salinas and Burney (Table 3). These are similar results to those found by Silva (2012) for broccoli hybrids of the Cabeça group in summer climate conditions, which presented grades of 2.93 to 5.00 for this characteristic. The presence of leaves in the inflorescence of broccoli of the Cabeça group can be induced by high temperature stress, causing differentiation of leaf buds in the inflorescence (BJORKMAM; PEARSON, 1998).

The cultivars with lower incidences of anthocyanin (purple pigmentation) in the inflorescence were Bibou, Burney, and Green Storm; and the cultivars BRO 68, Salinas, and TPX-00925 were the ones that most expressed this characteristic (Table 3). These are similar results to those described by Silva (2012) for tropical summer conditions, in which the cultivar BRO 68 presented high anthocyanin levels in the inflorescences, exhibiting a purplish pigmentation that is undesirable by consumers. This characteristic comes from the stress caused by excessive sunlight, since anthocyanins promote photoprotection in vegetables through better light absorption (ARAÚJO; DEMINICIS, 2009).

The cultivars with the highest flower bud sizes were Green Storm, Salinas, Bibou, and BRO 68 (Table 3). These cultivars showed greater ability to form flower buds with smaller sizes. According to Silva (2012), the cultivar BRO 68 has flower buds of coarse size with grade of 3.33 , and presents grades ranging from 2.20 to 5.00 for experimental and commercial hybrids. Moreover, the industry has required inflorescences with thin to medium flower buds to facilitate and reduce damages in the processing (SILVA, 2012).

Table 3. Grades for presence of leaves (PLI) and anthocyanin (PAI) in inflorescences, flower bud size (FBS), premature opening of flower buds in the inflorescence (POFBI), floret arrangement (FA), and hollow stem occurrence (HSO) in plants of broccoli cultivars of the Cabeça group grown in the hot and humid conditions of Central Amazonia. Manaus, AM, Brazil, 2016/2017.

\begin{tabular}{lcccccc}
\hline \multicolumn{1}{c}{ Cultivar } & PLI & PAI & FBS & POFBI & FA & HSO \\
\hline Bibou & $1.83 \mathrm{c}$ & $1.03 \mathrm{~b}$ & $3.55 \mathrm{a}$ & $4.08 \mathrm{a}$ & $1.30 \mathrm{~b}$ & $1.10 \mathrm{~b}$ \\
BRO 68 & $1.55 \mathrm{~d}$ & $1.63 \mathrm{a}$ & $3.53 \mathrm{a}$ & $4.05 \mathrm{a}$ & $1.30 \mathrm{~b}$ & $1.03 \mathrm{~b}$ \\
Burney & $4.13 \mathrm{a}$ & $1.08 \mathrm{~b}$ & $3.15 \mathrm{~b}$ & $3.48 \mathrm{~b}$ & $2.30 \mathrm{a}$ & $1.15 \mathrm{~b}$ \\
Green Storm & $2.08 \mathrm{c}$ & $1.15 \mathrm{~b}$ & $3.95 \mathrm{a}$ & $3.98 \mathrm{a}$ & $1.10 \mathrm{~b}$ & $1.85 \mathrm{a}$ \\
Salinas & $4.43 \mathrm{a}$ & $1.63 \mathrm{a}$ & $3.80 \mathrm{a}$ & $4.23 \mathrm{a}$ & $2.63 \mathrm{a}$ & $1.00 \mathrm{~b}$ \\
TPX-00925 & $3.43 \mathrm{~b}$ & $1.40 \mathrm{a}$ & $2.70 \mathrm{~b}$ & $3.13 \mathrm{~b}$ & $1.95 \mathrm{a}$ & $1.08 \mathrm{~b}$ \\
\hline Coefficient of variation (\%) & 7.9 & 15.7 & 13.2 & 12.3 & 19.9 & 7.2 \\
\hline
\end{tabular}

Means followed by the same letter in the columns are not different by the Scott Knott test at 5\% probability.

The cultivars with higher grades of premature opening of flower buds were Salinas, Bibou, BRO 68, and Green Storm (Table 3). Silva (2012) found $83 \%$ of the evaluated hybrids with little or no occurrence of premature flower bud opening. This is an undesirable characteristic of inflorescences and is related to an uneven maturation of flower buds due to high environmental temperatures, which reduce the commercial quality of inflorescences (MELO, 2015).

The cultivars that presented better floret arrangements, according to the assigned grades, were Salinas, Burney, and TPX00925 (Table 3); they showed better efficacy, with uniform distribution of biomass for floret formation. Silva (2012) found a mean grade of 1.55 for floret arrangement, and observed that $61 \%$ of the experimental hybrids did not differ from the commercial ones, forming acceptable inflorescences. This variable shows the visual aspect of inflorescence, which attracts the consumer by the cohesive floret arrangements and improves the efficiency of the industry processing.

Green Storm was the cultivar that present a higher occurrence of hollow stem (Table 3), showing its predisposition to this abnormality and its sensitivity to high temperatures. Campagnol et al. (2009) reported that this physiological disorder decreases as the rates for application of boron and nitrogen are increased; they found that this disorder occurred in $44 \%$ of plants grown in areas not fertilized with boron. Hollow stems may occur due to the predisposition of the cultivar, and extreme environmental factors, such as high temperature, drought, low relative air humidity, and inappropriate cultural practices of spacing, irrigation, and fertilization (MELO, 2015).

The cultivars that formed larger inflorescence stem diameters were Green Storm, Bibou, Burney, and BRO 68 (Table 4), denoting their efficiency for the formation of anatomical structures to support the inflorescence. Similar results were found by Seabra Júnior et al. (2014), who evaluated the yield of single -inflorescence broccoli cultivars under high temperature conditions and found diameters of 2.70 to $5.40 \mathrm{~cm}$; they reported a positive correlation between peduncle diameter and inflorescence production, which was confirmed in the present study. 
Table 4. Means for floral peduncle diameter (DPF), largest inflorescence diameter (LID), perpendicular to largest inflorescence diameter (PLID), relative inflorescence diameter (RID), inflorescence fresh weight (IFW), and inflorescence dry weight (IDW) of broccoli cultivars of the Cabeça group grown under the hot and humid conditions of Central Amazonia. Manaus, AM, Brazil, 2016/2017.

\begin{tabular}{|c|c|c|c|c|c|c|}
\hline \multirow{2}{*}{ Cultivar } & FPD & LID & PLID & RID & IFW & IDW \\
\hline & & cm & --- & & \multicolumn{2}{|c|}{---- g --- } \\
\hline Bibou & $4.17 \mathrm{a}$ & $11.05 \mathrm{~b}$ & $8.95 \mathrm{~b}$ & 1.25 & $245.16 b$ & $15.36 \mathrm{~b}$ \\
\hline BRO 68 & $3.91 \mathrm{a}$ & $13.53 \mathrm{a}$ & $10.74 \mathrm{a}$ & 1.28 & $237.87 \mathrm{~b}$ & $18.56 \mathrm{a}$ \\
\hline Burney & $4.15 \mathrm{a}$ & $13.61 \mathrm{a}$ & $11.39 \mathrm{a}$ & 1.20 & $225.05 \mathrm{~b}$ & $19.83 \mathrm{a}$ \\
\hline Green Storm & $4.33 \mathrm{a}$ & $12.84 \mathrm{a}$ & $9.88 \mathrm{~b}$ & 1.31 & $299.9 \mathrm{a}$ & $20.04 \mathrm{a}$ \\
\hline Salinas & $3.17 \mathrm{~b}$ & $10.55 \mathrm{~b}$ & $8.71 \mathrm{~b}$ & 1.22 & $179.92 \mathrm{c}$ & $13.77 \mathrm{~b}$ \\
\hline TPX-00925 & $2.84 \mathrm{~b}$ & $11.74 \mathrm{~b}$ & $9.34 \mathrm{~b}$ & 1.27 & $118.79 \mathrm{~d}$ & $11.59 \mathrm{~b}$ \\
\hline Coefficient of variation (\%) & 6.5 & 12.4 & 10.3 & 6.3 & 16.2 & 18.3 \\
\hline
\end{tabular}

Means followed by the same letter in the columns are not different by the Scott Knott test at 5\% probability.

Regarding the variable largest inflorescence diameter, the cultivars Burney, BRO 68, and Green Storm (Table 4) presented higher values. However, their results were lower than those found by Bhering (2013), who evaluated the effect of thermo-reflector, diffuser, and shading screens on the production of broccoli of the cultivar Maraton and found inflorescence diameters of 15.45 to $15.83 \mathrm{~cm}$. However, the results found in the present study for this characteristic are similar to those found by Melo et al. (2010), who evaluated the yield of singleinflorescence broccoli cultivars in the summer, under no-tillage, and found diameters of 13.10 to $15.30 \mathrm{~cm}$. This variable shows the inflorescence size and expresses the genetic potential of the cultivar, its ability to interact with environmental factors (CIANCALEONI et al., 2016), and the plant physiological and molecular responses that represent its tolerance to environmental stresses (ATKINSON; URWIN, 2012).

The cultivars that showed higher values for perpendicular to largest inflorescence diameter were Burney and BRO 68 (Table 4). The higher the value of this variable, the greater the cultivar's ability to prevent damages from sunlight and high temperatures to the photosynthetic structure, which cause photoinhibition, reducing photosynthetic activity and plant growth and yield (TAKAHASHI; BADGER, 2011).

Considering the relative diameter of the inflorescence, which indicates the cylindricity of the inflorescence, no differences between the evaluated cultivars were found (Table 4). Silva (2012) also found no significant differences at $5 \%$ probability level for this variable, with values ranging from 1.00 to 1.10 .

The cultivar Green Storm presented the highest inflorescence fresh weight (Table 4) in the Cabeça group, due to its better adaptation to the local edaphoclimatic conditions. The results were lower than those found by Bhering (2013) in the summer and autumn seasons in Viçosa, MG, Brazil (422.20 and $380.25 \mathrm{~g}$ ); but were similar results to those found by Melo et al. (2010), who evaluated yield of singleinflorescence broccoli cultivars in the summer, under no-tillage system, and found mean fresh inflorescence weights from 172.2 to $457.5 \mathrm{~g}$.

The cultivars that presented higher inflorescence dry weight were Green Storm, Burney, and BRO 68 (Table 4). However, these results were lower than those found by Bhering (2013) (27.23 to $37.76 \mathrm{~g})$ in the summer and autumn seasons, in Viçosa, MG.

The fresh and dry inflorescence weights show the ability of a cultivar to distribute assimilates to benefit commercially exploited parts of plants. Cultivars with higher weight gains are more efficient in intercepting light, in the photosynthetic conversion, assimilation of water and mineral by roots, and transport and redistribution of organic solutes. These cultivars have higher inflorescence yields by developing physiological and molecular defense mechanisms (AHANGER et al., 2017) to compensate stressful environmental conditions, such as high temperatures of hot and humid climates, by changing physiological and developmental processes to maintain growth and reproduction (TAIZ et al., 2017).

The most adapted and acclimatized broccoli cultivars to the hot and humid climate conditions of Central Amazonia were Piracicaba Precoce Verão, Verão Ramoso Piracicaba, Piracicaba Precoce, and Ramoso Santana (Ramoso group); and Green Storm and Burney (Cabeça group). These cultivars were tolerant to the effects of high temperatures on plant growth and development and inflorescence production. Their thermal plasticity prevents membrane and protein destabilization, photosynthetic and respiratory inhibition, production of reactive oxygen molecules, and cell death (ALLAKHVERDIEV et al., 2008).

\section{CONCLUSIONS}

The broccoli cultivars of the Ramoso group that produced the largest fresh flower bud weight were Verão Ramoso Piracicaba, Piracicaba Precoce Verão, Ramoso Santana, and Piracicaba Precoce; and the cultivars Verão Ramoso Piracicaba and 
Piracicaba Precoce Verão presented the highest number of inflorescences per plant and highest dry flower bud weight under the hot and humid conditions of Central Amazonia.

The cultivars Green Storm and Burney of the Cabeça group presented important characteristics for commercialization, such as large inflorescence diameter, high inflorescence dry weight, and low presence of anthocyanin in inflorescences.

\section{ACKNOWLEDGEMENTS}

To Embrapa Amazônia Ocidental; the Coordination for the Improvement of Higher Education Personnel (CAPES); the National Council for Scientific and Technological Development (CNPq); the Postgraduate Program in Tropical Agronomy, Faculty of Agricultural Sciences, Federal University of Amazonas for their support to this research.

\section{REFERENCES}

AHANGER, M. A. et al. Signal transduction and biotechnology in response to environmental stresses. Biologia Plantarum, 61: 401-416, 2017.

ALLAKHVERDIEV, S. I. et al. Heat stress: an overview of molecular responses in photosynthesis. Photosynthesis Research, 98: 541-550, 2008.

ALVARES, C. A. et al. Koppen's climate classification map for Brazil. Meteorologische Zeitschrift, 22: 711-728, 2013.

ARAÚJO, S. A. C.; DEMINICIS, B. B. Fotoinibição da fotossíntese. Revista Brasileira de Biociências, 7: 463-472, 2009.

ATKINSON, N. J.; URWIN, P. E. The interaction of plant biotic and abiotic stresses: from genes to the field. Journal of Experimental Botany, 63: 35233543, 2012.

BHERING, A. S. Efeito das malhas termorefletora, difusora e sombrite no crescimento e produtividade do brócolis. 2013. 39 f. Dissertação (Mestrado em Fitotecnia: Área de Concentração em Produção Vegetal) - Universidade Federal de Viçosa, Viçosa, 2013.

BJORKMAM, T.; PEARSON, K. J. High temperature arrest of inflorescence development in broccoli (Brassica oleraceavar. italicaL.). Journal of Experimental Botany, 49: 101-106, 1998.

BLIND, A. D. et al. Índice de rendimento em cultivares de brócolis tipo ramoso sob manejos de fertilização na Amazônia central. Scientia Plena, 11: $1-7,2015$.

BOOIJ, R.; STRUIK, P. C.. Effects of temperature on leaf and curd initiation in relation to juvenility of cauliflower. Scientia Horticulturae, 44: 201-214, 1990

CAMPAGNOL, R. et al. Boro e nitrogênio na incidência de hastes ocas e no rendimento de brócolis. Ciência e Agrotecnologia, 33: 1477-1485, 2009.

CIANCALEONI, S. et al.Broccoliyield response toenvironmentalfactors in sustainableagriculture. Europen Journal of Agronomy, 72: 1-9, 2016.

EMBRAPA. Sistema brasileiro de classificação de solos. 3 ed. Brasília: Embrapa, 2013. 353p.

GURURANI, M. A. et al. Regulation of Photosynthesis during Abiotic Stress-Induced Photoinhibition. Molecular Plant, 8: 1304-1320, 2015.

LALlA, J. G. et al. Competição de cultivares de brócolos tipo cabeça única em Campo Grande. Horticultura Brasileira, 28: 360-363, 2010.

LEAKEY, A. D. B. et al. Genomic basis for stimulated respiration by plants growin under elevated carbon dioxide. Proceedings of the National Academy of Sciences of the United States of America, 106: 3597-3602, 2009.

MELO, P. E.; GIORDANO, L. B. Couve-brócolos Ramoso de Brasília. Horticultura Brasileira, 17: 172-173, 1999.

MELO, R. A. C. et al. Cultivo de brócolos de inflorescência única no verão em plantio direto. Horticultura Brasileira, 28: 23-28, 2010.

MELO, R. A. C. et al. A cultura dos brócolis. Brasília, DF: EMBRAPA, 2015. 153 p. (Coleção Plantar, 74).

MELO, R. A. C. et al. Custos de produção e rentabilidade de brócolos de inflorescência única em sistemas de plantio direto e convencional. Horticultura Brasileira, 27: 3964-3970, 2009.

REIS, A.; MADEIRA, N. R. Diagnóstico dos principais problemas no cultivo de hortaliças no Estado do Amazonas. Brasília, DF: Embrapa Hortaliças, 2009. 12 p. (Circular Técnica, 82).

SEABRA JR., S. et al. Produção de cultivares de brócolis de inflorescência única em condições de 
altas temperaturas. Horticultura Brasileira, 32: 497 $-503,2014$.

SILVA, R. R. Desempenho de híbridos experimentais de couve brócolos do tipo cabeça única em condições de verão tropical. 2012. 36 p. Tese (Doutorado em Agronomia: Área de Concentração em Horticultura) - Universidade Estadual Paulista, Faculdade de Ciências Agronômicas, Botucatu, 2012.

TAIZ, L. et al. Fisiologia e desenvolvimento vegetal. 6. ed. Porto Alegre, RS: Editora Artmed, 2017.888 p.

TAKAHASHI, S.; BADGER, M. Photoprotection in plants: a new light on photosystem II damage. Trends in Plant Science, 16: 53-60, 2011.

TAN, D. K. Y. et al. Broccoli yield and quality can be determined by cultivar and temperature but not photoperiod in south-east Queensland. Australian Journal of Experimental Agriculture, 39: 901-909, 1999.

TRANI, P. E. et al. Brócolos, couve-flor e repolho. In: RAIJ, B. V. et al. Recomendações de adubação e calagem para o Estado de São Paulo. SP: Instituto Agronômico de Campinas, 1997. p. 175.

TREVISAN, J. N. Crescimento, desenvolvimento e produção de brócolis de cabeça única. 2013. $105 \mathrm{f}$. Dissertação (Mestrado em Agronomia: Área de Concentração em Produção Vegetal) - Universidade Federal de Santa Maria, Santa Maria, 2013.

TREVISAN, J. N. et al. Rendimento de cultivares de brócolis semeadas em outubro na região centro do Rio Grande do Sul. Ciência Rural, 33: 233-239, 2003.

WAHID, A. et al. Heat tolerance in plants: an overview. Environmental and Experimental Botany, 61: 199-223, 2007. 